\title{
PENGARUH TATA KELOLA PERUSAHAAN, KUALITAS AUDITOR DAN EARNING PER SHARE TERHADAP BID-ASK SPREAD
}

\author{
Rulyanto Winoto \\ Universitas Katolik Soegijapranata
}

\begin{abstract}
This study investigates the affect of audit committee size, board independence, auditor quality, and earnings per share on bid-ask spread. Population and sample in this study are all companies listed on the Indonesian Stock Exchange (BEI) from 2010 until 2014. The sampling technique in this research is using purposive sampling method. Data analysis tool used is the classic assumption test, test validity, reliability and hypothesis testing with multiple regression. Based on the analysis and discussion can be deduced as follows size of audit committee significant negative effect on the bid-ask spread, the independence of the board of commissioners significant positive effect on the bid-ask spread, quality auditor significant positive effect on bid-ask spreads and earnings per share (EPS) significant negative effect on the bid-ask spread.
\end{abstract}

Keywords: auditor quality, board independence, earnings per share, bid-ask spread.

\begin{abstract}
Abstrak
Penelitian ini bertujuan untuk apakah variabel ukuran komite audit, independensi dewan komisaris, kualitas auditor, dan earning per share (EPS) berpengaruh terhadap bid-ask spread. Populasi dan sampel pada penelitian ini adalah semua perusahaan yang terdaftar di Bursa Efek Indonesia (BEI) dari tahun 2010 sampai tahun 2014. Teknik pengambilan sampel dalam penelitian ini adalah menggunakan metode purposive sampling. Alat analisis data yang digunakan adalah uji asumsi klasik, uji validitas, reliabilitas dan uji hipotesis dengan regresi berganda. Berdasarkan pada hasil analisis dan pembahasan dapat ditarik kesimpulan sebagai berikut ukuran komite audit berpengaruh negatif signifikan terhadap bid-ask spread, independensi dewan komisaris berpengaruh positif signifikan terhadap bid-ask spread, kualitas auditor berpengaruh positif signifikan terhadap bid-ask spread dan earnings per share (EPS) berpengaruh negatif signifikan terhadap bid-ask spread.
\end{abstract}

Kata Kunci: kualitas auditor, independensi dewan komisaris, Earnings Per Share, bidask spread.

\section{PENDAHULUAN}

Peningkatan perekonomian suatu negara dapat didukung oleh berbagai faktor yang dapat meningkatkan perekonomian suatu negara, salah satunya adalah pasar modal. Pasar modal memiliki peran yang sangat penting dalam pembangunan nasional sebagai salah satu sumber pembiayaan bagi dunia usaha dan sarana investasi. Seiring dengan perkembangan pasar modal Indonesia, pemerintah Indonesia telah mengambil kebijakan yang telah menciptakan banyak peluang investasi dan mendorong perkembangan jumlah saham dalam upaya untuk meningkatkan kegiatan di pasar modal (Jogiyanto, 2008).

Menurut Komite Nasional Kebijakan Corporate Governance mengenai Komite Audit adalah:"Suatu komite yang beranggotakan satu atau lebih anggota Dewan Komisaris dan dapat meminta kalangan luar dengan berbagai keahlian, pengalaman, dan kualitas lain yang 
dibutuhkan untuk mencapai tujuan Komite Audit,pengertian Komite Audit adalah sebagai berikut:"Komite Audit adalah sekelompok orang yang dipilih oleh kelompok yang lebih besar untuk mengerjakan pekerjaan tertentu atau untuk melakukan tugas-tugas khusus atau sejumlah anggota Dewan Komisaris perusahaan klien yang bertanggungjawab untuk membantu auditor dalam mempertahankan independensinya dari manajemen."

Terdapat berbagai faktor yang mempengaruhi Bid ask spread, diantaranya adalah harga saham, volume perdagangan, laba per saham, serta komite audit. Penelitian Perdana dan Kristanti (2013) menyimpulkan bahwa harga saham, volume perdagangan, earning per share secara simultan berpengaruh signifikan terhadap Bid ask spread, tetapi secara parsial hanya variabel harga saham yang berpengaruh signifikan terhadap Bid ask spread.

Hasil penelitian Purwanto (2003) menunjukan harga saham, volume perdagangan, berpengaruh terhadap bid ask spread pada sebelum dan setelah right issue. Penelitian lain yang dilakukan oleh Napitupulu dan Syahyunan (2013) menyimpulkan bahwa volume perdagangan berpengaruh signifikan terhadap bid ask spread, tetapi return saham dan volatilitas harga saham tidak berpengaruh terhadap bid ask spread. Penelitian Paramita dan Yulianto (2014) menyimpulkan bahwa harga saham, volume perdagangan berpengaruh signifikan terhadap bid ask spread. Penelitian yang dilakukan oleh Tarjo (2010) menunjukan bahwa independensi dewan komisaris berpengaruh terhadap asimetri informasi yang diukur dari bid ask spread. Sementara Schauer (2001) menyatakan kualitas auditor berpengaruh terhadap bid ask spread.

Penelitian ini menguji kembali variabel-variabel yang berpengaruh terhadap bid-ask spread dengan menggabungkan variabel independen dari studi terdahulu yaitu ukuran komite audit, independensi dewan komisaris dan kualitas auditor serta laba per saham dengan menggunakan variabel kontrol yaituvolume perdagangan.

\section{TINJAUAN LITERATUR DAN PERUMUSAN HIPOTESIS}

\section{Pasar Modal}

Pasar modal adalah sarana untuk mempertemukan pihak-pihak yang memerlukan dana jangka panjang dengan pihak yang memiliki dana tersebut. Sedangkan pengertian pasar modal menurut Undang-Undang No. 8, tahun 1995 adalah: kegiatan yang bersangkutan dengan penawaran umum, perdagangan efek, perusahaan publik yang berkaitan dengan efek yang diterbitkannya, serta lembaga dan profesi yang berkaitan dengan efek. Efek dapat berupa saham, obligasi, surat pengakuan hutang, surat berharga komersial, dan sebagainya. Fungsi pasar modal adalah sebagai sumber dana jangka panjang, alternative investasi, alat restrukturisasi modal perusahaan, dan alat untuk melakukan investasi.

\section{Mekanisme Transaksi Pasar Modal}

Perdagangan saham terjadi di pasar sekunder yang merupakan pasar bagi efek yang telah dicatatkan di bursa. Dengan kata lain pasar sekunder merupakan pasar dimana pemodal dapat melakukan jual beli efek setelah efek tersebut tercatat di bursa,jadi pasar sekunder merupakan kelanjutan dari pasar perdana. Di Indonesia terdapat satu bursa efek yaitu Bursa Efek Indonesia, sebagai tempat berlangsungnya perdagangan efek di pasar sekunder.

\section{Pentingnya Informasi dalam transaksi}

Informasi yang dipublikasikan yang mempengaruhi harga-harga sekuritas semua perusahaan yang terdaftar di pasar saham. Informasi ini dapat berupa peraturan pemerintah atau peraturan dari regulator yang berdampak pada semua perusahaan emiten. Contoh: peraturan akuntansi untuk mencantumkan laporan arus kas yang harus dilakukan oleh semua perusahaan. Regulasi ini akan berdampak pada semua harga sekuritas tidak hanya sebuah 
perusahaan, tetapi mungkin berdampak langsung pada semua perusahaan.Dalam kondisi pasar efisien bentuk setengah kuat ini, harga saham sangat sensitif terhadap kedatangan informasi-informasi baru dan tidak ada investor atau grup dari investor yang dapat menggunakan informasi yang dipublikasikan untuk mendapatkan keuntungan tidak normal dalam jangka waktu yang lama (Jogiyanto, 2012).

\section{Teori Sinyal}

Teori sinyal menjelaskan alasan perusahaan menyajikan informasi untuk pasar modal. Teori sinyal menunjukkan adanya asimetri informasi antara manajemenperusahaan dan pihak-pihak yang berkepentingan dengan informasi tersebut. Teori sinyal mengemukakan tentang bagaimana seharusnya perusahaan memberikan sinyal-sinyal pada pengguna laporan keuangan.Menurut Jama'an (2008), Signaling Theory mengemukakan tentang bagaimana seharusnya sebuah perusahaan memberikan sinyal kepada pengguna laporan keuangan. Sinyal ini berupa informasi mengenai apa yang sudah dilakukan oleh manajemen untuk merealisasikan keinginan pemilik. Sinyal dapat berupa promosi atau informasi lain yang menyatakan bahwa perusahaan tersebut lebih baik daripada perusahaan lain.

\section{Bid Ask Spread}

Bid-ask spread yaitu selisih harga antara harga permintaan beli dengan penawaran jual (Wisayang,2010) Hal tersebut merupakan salah satu faktor yang dipertimbangkan oleh para investor dalam mengambil keputusan apakah menahan atau menjual saham tersebut. Menurut Subali.et.al (2002) menyatakan bahwa bid-ask spread merupakan fungsi dari transaction cost diprediksi bahwa asset yang memiliki spread yang lebih besar menghasilkan expected return yang lebih tinggi pula, akibatnya investor mengharapkan holdingperiod yang panjang.

\section{Ukuran Komite Audit}

Keanggotaan komite audit sekurang-kurangnya satu orang Komisaris Independen dan sekurang-kurangnya dua orang anggota lainnya berasal dari luar emiten atau perusahaan publik. Anggota komite audit yang merupakan komisaris independen bertindak sebagai ketua komite audit. Komite audit bertugas untuk memberikan pendapat kepada Dewan Komisaris terhadap laporan atau hal-hal yang disampaikan oleh direksi kepada Dewan Komisaris (Bapepam Kep-305/BEJ/07-2004). Komite audit juga bertugas sebagai pihak penengah apabila terjadi selisih pendapat antara menajemen dan auditor mengenai interpretasi dan penerapan prinsip akuntansi yang berlaku umum untuk mencapai keseimbangan akhir sehingga laporan lebih akurat

\section{Independensi Dewan Komisaris}

Karakteristik dewan komisaris secara umum dan khususnya komposisi dewan dapat menjadi suatu mekanisme yang menentukan tindakan manajemen laba. Jensen dan Meckling (1976) menyatakan bahwa ukuran dewan komisaris merupakan bagian dari mekanisme corporate governance. Dewan komisaris merupakan mekanisme governance yang penting. Mereka juga menyarankan bahwa dewan komisaris yang ukurannya besar kurang efektif daripada dewan yang ukurannya kecil. Ukuran dan komposisi dewan direksi dapat mempengaruhi efektif tidaknya aktivitas monitoring. Ukuran dan komposisi dewan direksi juga mempengaruhi hubungan kepemilikan manajerial dan kepemilikan institusional terhadap kinerja perusahaan.

\section{Kualitas Auditor}

Kalangan bisnis dan pengguna jasa akuntan publik, umumnya mengelompokkan KAP menjadi dua yaitu : 
1. Big Four, terdiri dari : KAP Ernst \& Young, Delloite Thouch Tohmatsu, KPMG, Price Waterhouse Coopers. Menurut Wikipedia, The Big Four adalah suatu kelompok kantor akuntan internasional yang menangani bagian terbesar pekerjaan audit dari perusahaanperusahaan publik. Jika ditelusuri, sejarah pendirian masing-masing anggota the Big Four kebanyakan berasal dari Eropa.

2. Non Big Four terdiri dari beberapa KAP nasional dengan afiliasi internasional yang memiliki penghasilan lebih rendah daripada Big Four dan juga KAP regional / lokal yang memiliki satu kantor atau lebih.

Kualitas audit selalu diasosiasikan dengan ukuran kantor akuntan (Butar Butar, 2014). Mengutip DeAngelo (1981), Butar Butar (2014) mengatakan bahwa penghasilan besar yang diperoleh kantor akuntan berukuran besar menempatkan mereka dalam posisi yang lebih rentan dibanding auditor kecil ketika mengalami kegagalan audit.

\section{Earnings Per Share}

Earnings Per Share (EPS) atau laba per lembar saham adalah tingkat keuntungan bersih untuk tiap lembar sahamnya yang mampu diraih perusahaan pada saat menjalankan operasinya. Laba per lembar saham atau EPS di peroleh dari laba yang tersedia bagi pemegang saham biasa dibagi dengan jumlah rata - rata saham biasa yang beredar.Salah satu alasan investor membeli saham adalah untuk mendapatkan deviden, jika nilai laba per saham kecil maka kecil pula kemungkinan perusahaan untuk membagikan deviden. Maka dapat dikatakan investor akan lebih meminati saham yang memiliki earnings per share tinggi dibandingkan saham yang memiliki earnings per share rendah. Hal ini dikarenakan earnings per share yang rendah cenderung membuat harga saham turun.

\section{Pengembangan Hipotesis}

\section{Pengaruh Ukuran Komite Audit terhadap Bid-Ask Spread}

Tugas komite audit berkaitan dengan kualitas laporan keuangan, karena peran utama komite audit adalah membantu Dewan Komisaris dalam hal pengawasan laporan keuangan oleh manajemen. Dengan demikian, komite audit memegang peranan sangat penting dalam mekanisme pengendalian internal perusahaan. Penelitian lain yang dilakukan oleh Wakum dan Wisadha (2014) menunjukkan bahwa variabel keberadaan komite audit terbukti mampu memperlemah pengaruh negatif audit tenure pada asimetri informasi yang diukur dengan bid ask spread. Penelitian dari wakum dan wisadha (2014) menyatakan hal yang sama dimana komite audit berpengaruh signifikan terhadap bid-ask spread. Semakin banyak jumlah anggota komite audit mengindikasikan bahwa komite audit memiliki peran lebih dalam membantu dewan komisaris dalam hal pengawasan laporan keuangan sehingga akan lebih baik monitoring perusahaan dan berdampak pada kualitas laporan keuangan sehingga menurunkan bid-ask spread Ketika komite audit melakukn tugas pengawasannya secara efektif maka hasil laporan keuangan dari perusahaan akan merefleksikan hasil dari pengawasan komite audit. Sehingga hal ini akan menyebabkan bid ask spread mengecil karena fungsi pengawasan yang baik dari komite audit. Maka hipotesis pada penelitian ini adalah:

\section{H1: Ukuran komite audit berpengaruh negatif terhadap bid-ask spread.}

\section{Pengaruh Independensi Dewan Komisaris terhadap Bid-Ask Spread}

Kekhawatiran penyalahgunaan wewenang oleh direksi perusahaan semakin menegaskan arti penting Dewan Komisaris sebagai perwakilan pemegang saham di dalam perusahaan (Butar Butar, 2014). Keberadaan dewan komisaris diharapkan melindungi hak-hak pemegang sahamminoritas agar tidak terabaikan. Komposisi dewan komisaris yang memadai danperan 
aktifnya dalam menjalankan kegiatan roda bisnis perusahaan akanmendorong manajemen untuk bekerja keras berdasarkan mandat yang diterimadari pemilik. Chtourou et al. (2001) memberi bukti bahwa peran aktif dewankomisaris dalam proses pelaporan keuangan akan membatasi manajemenmelakukan kecurangan melalui manajemen laba dan asimetri informasi. Balling et al. (2005) membuktikan bahwa pemeringkatan mekanisme tata kelola korporat yang salah satu indikatornya adalah keberadaan peran aktif dewan komisaris mampu menurunkan permasalahan asimetri informasi antaraperusahaan dan para investor. Turunnya asimetri informasi akan meningkatkanpermintaan sekuritas dan harga pasar saham sehingga akan menurunkan bid ask spread Penelitian yang dilakukan oleh Tarjo (2010) menemukan bahwa independensi Dewan Komisaris berpengaruh terhadap asimetri informasi yang diukur dari bid ask spread. Semakin tinggi independensi dewan komisaris mengindikasikan bahwa dewan komisaris bekerja dengan efektif dalam menjalankan tugasnya dalam perusahaan sehingga ini menunjukkan sinyal positif kepada para investor, dengan demikian harga saham akan cenderung makin stabil dan berdampak pada menurunnyabid ask spread. Berdasarkan pada uraian tersebut maka penelitian ini mengajukan hipotesis sebagai berikut:

H2: Independensi dewan komisaris berpengaruh negatif terhadap bid-ask spread.

\section{Pengaruh Kualitas Auditor terhadap Bid-Ask Spread}

KAP besar memiliki frekuensi mengaudit yang tinggi. Semakin sering auditor dalam melakukan audit terhadap laporan keuangan maka akan semakin berpengalaman dan berkualitas sehingga memungkinkan mereka bekerja dengan efektif. Perusahaan yang telah memilih KAP yang termasuk dalam Big Fourmengindikasikan kualitas auditor yang baik. Penelitian Schauer (2001) menemukan kualitas auditor berpengaruh terhadap bid ask spread. Semakin baik kualitas auditor maka ini merupakan good news atau sinyal positif bagi investor dan harga saham akan semakin stabil, sehingga berdampak pada menurunnya bid ask spread. Ketika perusahaan yang mengaudit adalah KAP Big Four berarti ada kecenderungan untuk melaksanakan tugas dengan lebih baik karena lebih profesional dan memiliki keahlian lebih baik sehingga hasil dari laporan keuangan semakin kredibel dan menarik investor untuk berinvestasi, harga akan semakin stabil, yang akan memperkecil bid ask spread.Berdasarkan pada uraian tersebut maka penelitian ini mengajukan hipotesis sebagai berikut:

\section{H3: Kualitas auditor berpengaruh negatif terhadap bid-ask spread.}

\section{Pengaruh Earnings Per Share (EPS)terhadap bid-ask spread.}

$E P S$ atau laba per lembar saham adalah tingkat keuntungan bersih untuk tiap lembar sahamnya yang mampu diraih perusahaan pada saat menjalankan operasinya. Laba per lembar saham atau EPS di peroleh dari laba yang tersedia bagi pemegang saham biasa dibagi dengan jumlah rata - rata saham biasa yang beredar.sehingga dapat menunjukan bahwa spread harga saham cenderung menjadi lebih sempit pada saat tingkat laba per saham dari saham perusahaan tersebut tinggi. Penelitian Perdana dan Kristanti (2013) juga mendukung hal tersebut dimana semakin tinggi EPS menunjukkan bahwa perusahaan semakin baik kinerjanya, hal ini adalah berita baik bagi investor dan menarik minat investor untuk berinvestasi sehingga akan membuat harga saham di pasaran semakin stabil, pada akhirnya akan menurunkan bid ask spread. Maka hipotesisnya adalah:

H4: Earnings per share berpengaruh negatif terhadap bid-ask spread. 


\section{METODE PENELITIAN}

\section{Populasi dan Sampel}

Populasi dalam penelitian ini adalah semua perusahaan yang terdaftar di Bursa Efek Indonesia (BEI) dari tahun 2010 sampai tahun 2014.Sampel penelitian ini adalah perusahaanperusahaan dari tahun 2010 sampai tahun 2014. Teknik pengambilan sampel dalam penelitian ini adalah menggunakan metode purposive sampling, yaitu pemilihan sampel secara tidak acak yang disesuaikan dengan tujuan atau target tertentu. Adapun kriterianya adalah sebagai berikut:

1. Perusahaan yang terdaftar di BEI tahun 2010-2014.

2. Perusahaan tidak didelisting dari BEI selama periode pengamatan

3. Perusahaan yang datanya tersedia dan dapat diakses

4. Perusahaan memiliki data tentang variabel penelitian yaitu: bid ask spread,komite audit, kualitas auditor, independensi dewan komisatis, return, EPS, volume perdagangan.

\section{Jenis dan Sumber Data}

Jenis data yang digunakan adalah data sekunder. Sumber data diperoleh dari Pojok Bursa Efek Indonesia di Semarang dan Kantor IDXCabang Semarang, yahoo finance.

\section{Desain Analisis Data \\ Statistik Deskriptif}

Analisis statistik deskriptif digunakan untuk mengetahui nilai statistik variabelvariabel yang digunakan dalam penelitian. Dengan statistik deskriptif dapat diketahui nilai rata-rata (mean) data, nilai minimum dan maksimum, range data, dari variabel-variabel yang diteliti.

\section{Uji Asumsi Klasik}

\section{Uji Normalitas}

Dalam penelitian ini uji normalitas dideteksi dengan uji statistik. Uji statistik yang dipakai dalam penelitian ini yaitu uji Kolmogorov-Smirnov. Jika nilai Kolmogorov-Smirnov memiliki tingkat signifikan di atas $\alpha=0,05$ berarti suatu variabel dikatakan berdistribusi normal.

\section{Uji Multikolonieritas}

Pengujian ini dilakukan untuk menguji apakah dalam model regresi ditemukan adanya korelasi antar variabel bebas (Ghozali, 2011). Hal ini dapat dilakukan dengan melihat nilai tolerance dan nilai variance inflation factor (VIF) dengan kriteria sebagai berikut:

1. Jika nilai tolerance $>0,1$ atau nilai $\mathrm{VIF}<10$, berarti tidak terjadi multikolonieritas.

2. Jika nilai tolerance $<0,1$ atau nilai VIF $>10$, berarti terjadi multikolonieritas.

\section{Uji Autokorelasi}

Pengujian ini dilakukan untuk menguji apakah dalam model regresi linear ditemukan adanya korelasi antara kesalahan penggangu pada periode $t$ dengan kesalahan pada periode $t$ 1 (sebelumnya). Uji autokorelasi dapat dilakukan dengan uji Durbin-Watson (Ghozali, 2011), dengan kriteria sebagai berikut:

1. Bila nilai DW terletak antara batas atas atau upper bound (du) dan (4-du), maka koefisien aoutokorelasi $=0$, sehingga tidak ada autokorelasi.

2. Bila nilai DW lebih rendah daripada batas bawah atau lower bound (dl), maka koefisien autokorelasi $>0$, sehingga ada autokorelasi positif. 
3. Bila nilai DW lebih besar daripada (4-dl), maka koefisien autokorelasi $<0$, sehingga ada autokorelasi negatif.

4. Bila nilai DW terletak diantara batas atas (du) dan batas bawah (dl) atau DW terletak antara (4-du) dan (4-dl), maka hasilnya tidak dapat disimpulkan.

\section{Uji Heteroskedastisitas}

Pengujian ini dilakukan untuk menguji apakah dalam model regresi terjadi ketidaksamaan variance dari residual satu pengamatan ke pengamatan yang lain. Uji heteroskedastisitas dalam penelitian ini dilakukan dengan uji Glejser. Uji Glejser dilakukan dengan meregres nilai absolut residual terhadap variabel independen. Jika nilai variabel independen secara signifikan mempengaruhi variabel dependen (nilai Sig. $<0,05$ ) maka ada indikasi terkena heteroskedastisitas.

\section{Pengujian Hipotesis}

Untuk menguji pengaruh antara variabel independen terhadapvariabel dependen, maka penelitian ini menggunakan alat uji regresi linier berganda. Model Regresi yang digunakan untuk pengujian hipotesis:

$$
\mathrm{SPREAD}=\beta_{0}+\beta_{1} \mathrm{UKA}+\beta_{2} \mathrm{IDK}+\beta_{3} \mathrm{KA}+\beta_{4} \mathrm{EPS}+\beta_{5} \mathrm{TVA}+\varepsilon_{\mathrm{it}}
$$

Keterangan:

$\begin{array}{ll}\text { SPREAD } & : \text { Bid ask spread } \\ \text { UKA } & \text { :Ukuran komite audit } \\ \text { IDK } & \text { : Independensi dewan komisaris } \\ \text { KA } & : \text { Kualitas auditor } \\ \text { EPS } & : \text { Laba per saham (EPS) } \\ \text { TVA } & : \text { Volume perdagangan }\end{array}$

\section{HASIL DAN PEMBAHASAN}

\section{Statistik Deskriptif}

Tabel 1. Statistik Deskriptif

\begin{tabular}{|l|r|r|r|r|r|}
\hline & $\mathrm{N}$ & Minimum & Maximum & Mean & Std. Deviation \\
\hline SPREAD & 931 &,- 07 &, 17 &, 010 &, 041 \\
UKA & 931 & 1,00 & 7,00 & 3,081 &, 559 \\
IDK & 931 &, 14 & 1,00 &, 487 &, 167 \\
KA & 931 &, 00 & 1,00 &, 407 &, 491 \\
EPS & 931 & $-314,74$ & 24074,00 & 170,312 & 1090,718 \\
TVA & 931 &, 00 & 13,72 &, 336 &, 566 \\
Valid N & 931 & & & & \\
(listwise) & & & & \\
\hline
\end{tabular}

Sumber: Data Sekunder yang Diolah

Berdasarkan tabel 1 dapat diketahui bahwa ukuran komite audit (UKA) memiliki nilai minimum sebesar 1 dan maksimum 7. Artinya jumlah komite audit yang paling rendah 1 orang yaitu pada PT Multi Bintang Tbk dan jumlah komite audit paling tinggi 7 orang 
yaitu pada PT Aneka Tambang Tbk. Nilai rata-rata sebesar 3,081 yang artinya rata-rata perusahaan pada penelitian ini memiliki komite audit sekitar 3 orang.

\section{Hasil Pengujian Asumsi Klasik}

Uji asumsi klasik pada penelitian ini dilakukan dengan uji normalitas, multikolinearitas, autokorelasi dan uji heteroskedastisitas:

\section{Uji Normalitas}

Untuk pengujian normalitas data pada penelitian ini dilakukan dengan menggunakan uji Kolmogorov Sminov. Untuk menormalkanya peneliti menghapus data yang ekstrim dan melakukan pengujian kembali pada data tersebut apakah berdistribusi normal atau tidak:

\section{Tabel 2. Hasil Uji Normalitas Awal}

\begin{tabular}{|l|r|r|r|r|r|r|}
\hline & \multicolumn{3}{|c|}{ Kolmogorov-Smirnov $^{\text {a }}$} & \multicolumn{3}{c|}{ Shapiro-Wilk } \\
\cline { 2 - 7 } & Statistic & Df & \multicolumn{1}{c|}{ Sig. } & Statistic & \multicolumn{1}{c|}{ df } & \multicolumn{1}{c|}{ Sig. } \\
\hline Unstandardized Residual &, 234 & 1436 &, 000 &, 731 & 1436 &, 000 \\
\hline
\end{tabular}

Tabel 3. Hasil Uji Normalitas Akhir

\begin{tabular}{|l|r|r|r|r|r|r|}
\hline & \multicolumn{3}{|c|}{ Kolmogorov-Smirnov $^{\text {a }}$} & \multicolumn{3}{c|}{ Shapiro-Wilk } \\
\cline { 2 - 7 } & Statistic & Df & \multicolumn{1}{c|}{ Sig. } & Statistic & \multicolumn{1}{c|}{ df } & \multicolumn{1}{c|}{ Sig. } \\
\hline Unstandardized Residual &, 026 & 931 &, 121 &, 996 & 931 &, 019 \\
\hline
\end{tabular}

Berdasarkan pada tabel 2 dan tabel 3 di atas dapat disimpulkan bahwa hasil pengujian untuk normalitas akhir dapat dilihat dari nilai Kolmogorof-Smirnov sig. sebesar 0,121>0,05 dapat dikatakan bahwa data pada penelitian ini telah normal.

\section{Uji Multikolinearitas}

Pengujian yang digunakan untuk mengetahui apakah antar variabel independen terjadi korelasi atau tidak. Untuk mengetahui ada tidaknya multikolinearitas maka dapat dilihat dari nilai VIF (Variance Inflation Factor) dan Tolerance. Jika nilai VIF $<10$ dan Tolerance $>0,1$, maka dipastikan tidak terjadi multikolinearitas. Berikut ini adalah hasilnya:

Tabel 4. Hasil Pengujian Multikolinearitas

\begin{tabular}{|ll|r|r|}
\hline \multirow{2}{*}{ Model } & & \multicolumn{2}{|c|}{ Collinearity Statistics } \\
\cline { 3 - 4 } & & Tolerance & \multicolumn{1}{c|}{ VIF } \\
\hline 1 & (Constant) & & \\
& UKA &, 953 & 1,050 \\
& IDK &, 988 & 1,012 \\
& KA &, 945 & 1,059 \\
& EPS &, 976 & 1,024 \\
& TVA &, 997 & 1,003 \\
\hline
\end{tabular}

Berdasarkan pada tabel 4 di atas dapat di simpulkan bahwa hasil pengujian untuk multikolinearitas memiliki nilai Tolerance untuk masing-masing variable independen $>0,1$ dan untuk nilai VIF $<10$ sehingga dapat dikatakan tidak terjadi multikolinearitas pada penelitian ini. 


\section{Uji Autokorelasi}

Uji autokorelasi di gunakan untuk mengetahuada tidaknya kolerasi dalam suatu model regresi yang dilakukan dengan uji Durbin Watson (DW) di katakan tidak terjadi autokorelasi jika $\mathrm{du}<\mathrm{dw}<4$-du. Sehingga di peroleh basil sebagai berikut:

Tabel 5. Hasil Pengujian Autokorelasi

\begin{tabular}{|l|r|r|r|r|r|}
\hline Model & $\mathrm{R}$ & R Square & $\begin{array}{c}\text { Adjusted R } \\
\text { Square }\end{array}$ & $\begin{array}{c}\text { Std. Error of } \\
\text { the Estimate }\end{array}$ & $\begin{array}{l}\text { Durbin- } \\
\text { Watson }\end{array}$ \\
\hline 1 &, $175^{\mathrm{a}}$ &, 030 &, 025 &, 04020 & 1,515 \\
\hline
\end{tabular}

Berdasarkan pada tabel 5 di atas dapat diketahui bahwa hasil pengujian untuk autokorelasi sebesar 1,515 berada diantara 1,5 dan 2,5 artinya tidak terjadi autokorelasi pada penelitian ini.

\section{Uji Heteroskedastisitas}

Dalam penelitian ini untuk menguji heterokedastisitas digunakan uji Glejser. Dalam uji Glejser, nilai mutlak residual ( $|\mathbf{u}|$ ) diregresikan dengan variabel independen. Berikut ini adalah hasil pengujiannya:

Tabel 6. Hasil Pengujian Heteroskedastisitas

\begin{tabular}{|c|c|c|c|c|c|c|}
\hline \multirow{2}{*}{\multicolumn{2}{|c|}{ Model }} & \multicolumn{2}{|c|}{ Unstandardized Coefficients } & \multirow{2}{*}{$\begin{array}{c}\begin{array}{c}\text { Standardized } \\
\text { Coefficients }\end{array} \\
\text { Beta }\end{array}$} & \multirow[b]{2}{*}{$\mathrm{t}$} & \multirow[b]{2}{*}{ Sig. } \\
\hline & & $\mathrm{B}$ & Std. Error & & & \\
\hline \multirow[t]{6}{*}{1} & (Constant) & ,940 &, 123 & & 7,652 &, 000 \\
\hline & UKA &,- 053 & ,036 &,- 050 & $-1,487$ &, 137 \\
\hline & IDK &,- 032 & , 118 &,- 009 &,- 276 & ,783 \\
\hline & KA &, 010 &, 041 &, 008 & ,244 &, 807 \\
\hline & EPS & $7,060 \mathrm{E}-7$ & 000 & 001 & ,039 & ,969 \\
\hline & TVA &,- 018 & 035 &,- 017 &,- 514 & 607 \\
\hline
\end{tabular}

Berdasarkan pada tabel 6 dapat di dimpulkan bahwa hasil pengujian heteroskedastisitas untuk masing-masing variable independen memiliki nilai signifikansi di atas 0,05 sehingga dengan demikian dapat dikatakan tidak terjadi heteroskedastisitas.

\section{Hasil Uji Koefisien Determinasi}

Tabel 7. Hasil Pengujian Koefisien Determinasi

\begin{tabular}{|l|r|r|r|r|r|}
\hline Model & \multicolumn{1}{|c|}{$\mathrm{R}$} & R Square & $\begin{array}{c}\text { Adjusted R } \\
\text { Square }\end{array}$ & $\begin{array}{c}\text { Std. Error of } \\
\text { the Estimate }\end{array}$ & $\begin{array}{l}\text { Durbin- } \\
\text { Watson }\end{array}$ \\
\hline 1 &, $175^{\mathrm{a}}$ &, 030 &, 025 &, 04020 & 1,515 \\
\hline
\end{tabular}

Berdasarkan pada tabel 7 di atas dapat di simpulkan bahwa hasil pengujian untuk Adjusted R Square sebesar 0,025 artinya variabel independen mempengaruhi dependen sebesar $2,5 \%$ 


\section{Pengujian Hipotesis}

Setelah semua asumsi terpenuhi, maka berikutnya adalah melakukan pengujian hipotesis untuk mengetahui pengaruh variabel independen terhadap variabel dependen. Pengujian dilakukan dengan menggunakan uji t dengan hasil sebagai berikut:

Tabel 8. Hasil Pengujian Faktor yang mempengaruhi Bid Ask Spread

\begin{tabular}{|c|c|c|c|c|c|c|c|c|}
\hline \multirow{2}{*}{\multicolumn{2}{|c|}{ Model }} & \multicolumn{2}{|c|}{$\begin{array}{l}\text { Unstandardized } \\
\text { Coefficients }\end{array}$} & \multirow{2}{*}{$\begin{array}{c}\begin{array}{c}\text { Standardize } \\
\mathrm{d} \\
\text { Coefficients }\end{array} \\
\text { Beta }\end{array}$} & \multirow[b]{2}{*}{ 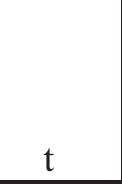 } & \multirow[b]{2}{*}{ Sig. } & \multirow[t]{2}{*}{ Sig./2 } & \multirow{2}{*}{$\begin{array}{c}\text { Kesimpula } \\
\mathrm{n}\end{array}$} \\
\hline & & B & Std. Error & & & & & \\
\hline \multirow[t]{6}{*}{1} & (Constant) &, 012 & ,008 & & 1,498 & ,135 & & \\
\hline & UKA &,- 005 & ,002 &,- 073 & $-2,186$ & ,029 & ,015 & Terima \\
\hline & IDK & ,022 & ,008 & ,092 & 2,816 & ,005 & ,003 & Tolak \\
\hline & KA & ,009 & ,003 & ,108 & 3,250 & 001 & ,0005 & Tolak \\
\hline & EPS & $-4,116 \mathrm{E}-6$ &, 000 &,- 110 & $-3,366$ & ,001 & ,0005 & Terima \\
\hline & TVA &, 000 & ,002 & ,004 & ,138 & 890 & & Tolak \\
\hline
\end{tabular}

\section{Pengaruh ukuran komite audit terhadap bid-ask spread}

Dari tabel 8 diketahui nilai sig. untuk variabel UKA adalah sebesar 0,029/2 $=0,015<$ 0,05 dengan nilai koefisien regresi negatif, sehingga artinya hipotesis pertama pada penelitian ini diterima. Jadi terdapat pengaruh negatif antara UKA terhadap bid-ask spread. Pengujian hipotesis pertama pada penelitian ini diterima. Artinya ukuran komite audit berpengaruh negatif terhadap bid-ask spread. Jadi semakin tinggi ukuran komite audit akan menurunkan nilai bid-ask spread perusahaan karena semakin banyak jumlah komite audit menunjukkan adanya indikasi kinerja yang semakin baik dan ini merupakan good news bagi investor, dan pada akhirnya berdampak pada semakin menurunnya bid-ask spread.

\section{Pengaruh independensi dewan komisaris terhadap bid-ask spread}

Dari tabel 8 diketahui nilai sig. untuk variabel IDK adalah sebesar 0,005/2=0,003< 0,05 tetapi berbeda arah koefisien regresi sehingga artinya hipotesis kedua pada penelitian ini ditolak. Jadi IDK berpengaruh positif signifikan terhadap bid-ask spread. Hasil pengujian hipotesis kedua menyatakan bahwa IDK berpengaruh positif terhadap bid-ask spread. Maka semakin tinggi independensi dewan komisaris akan berdampak pada meningkatnya nilai bidask spread perusahaan. Hal ini disebabkan karena semakin banyak dewan komisaris independen akan rentan munculnya konflik kepentingan sehingga akan menurunkan efektivitas kinerjanya, ini merupakan bad news bagi investor sehingga hasilnya akan meningkatkan bid-ask spread.

\section{Pengaruh kualitas auditor terhadap bid-ask spread}

Dari tabel 8 diketahui nilai sig. untuk variabel KA adalah sebesar $0,001 / 2=0,0005<$ 0,05 dan koefisien regresi positif sehingga artinya hipotesis ketiga pada penelitian ini ditolak. Jadi KA berpengaruh positif dan signifikan terhadap bid-ask spread. Hasil pengujian hipotesis ketiga membuktikan bahwa KA berdampak positif pada bid-ask spread. Maka hipotesis ditolak. Hal ini berarti perusahaan yang diaudit non big four untuk meningkatkan reputasinya akan berusaha lebih keras dalam melakukan audit laporan keuangan sehingga bid ask spread akan mengecil.

\section{Pengaruh earnings per share (EPS) terhadap bid-ask spread}

Dari tabel 8 diketahui nilai sig.untuk variabel earning per share (EPS) adalah sebesar $0,001 / 2=0,0005<0,05$ dengan nilai beta negatif sehingga artinya hipotesis keempat pada 
penelitian ini diterima. Jadi (EPS) berpengaruh negatif signifikan terhadap bid-ask spread. Berdasarkan pada hasil pengujian hipotesis keempat diketahui bahwa terdapat pengaruh negatif signifikan antara EPS terhadap bid-ask spread. Laba per saham merupakan perbandingan antara jumlah Earning (dalam hal ini laba bersih yang siap dibagikan bagi pemegang saham) dengan jumlah lembar saham perusahaan. Tingkat laba per saham yang tinggi dapat menunjukan bahwa perusahaan tersebut memiliki kemampuan menghasilkan laba yang baik. Sehingga tercipta indikasi bahwa perusahaan tersebut memiliki prospek yang baik untuk kedepannya. Investor melihat tingkat laba per saham suatu perusahaan sebagai salah satu informasi untuk mendukung investor untuk memilih di saham perusahaan mana ia akan berinvestasi.investor akan cenderung memilih saham dari perusahaan yang memiliki tingkat laba per saham yang tinggi karena investor berasumsi bahwa perusahaan tersebut akan menghasilkan keuntungan yang optimal dari investasinya. Hal ini mengakibatkan saham dari perusahaan yang memiliki tingkat laba per saham yang tinggi cenderung diminati oleh investor sehingga saham tersebut akan aktif diperdagangkan. Saham yang aktif diperdagangkan akan membuat para pelaku pasar memiliki kecenderungan untuk tidak menahan saham tersebut dalam suatu jangka waktu dan melepas kepemilikan sahamnya pada saham tersebut aktif diperdagangkan. Hasil penelitian ini menyatakan bahwa EPS berpengaruh negatif terhadap spread karena perusahaan dengan EPS tinggi merupakan good news sehingga akan menurunkan bid-ask spread.

\section{Variabel Kontrol}

Dari tabel 8 diketahui nilai sig. untuk variabel TVA adalah sebesar $0,890>0,05$ sehingga artinya TVA tidak dapat menjadi variabel kontrol.

\section{SIMPULAN}

\section{Kesimpulan}

Berdasarkan pada hasil analisis data dapat ditarik kesimpulan sebagai berikut:

a. Ukuran komite audit berpengaruh negatif signifikan terhadap bid-ask spread.

b. Independensi dewan komisaris berpengaruh positif signifikan terhadap bid-ask spread.

c. Kualitas auditor berpengaruh positif signifikan terhadap bid-ask spread.

d. Earnings per share (EPS) berpengaruh negatif signifikan terhadap bid-ask spread.

\section{Saran}

Sedangkan saran yang dapat dikemukakan pada penelitian ini adalah: Pada penelitian mendatang dengan topik serupa dapat ditambahkan variabel lain yang mempengaruhi bid-ask spread dan menambah tahun pengamatan, seperti kepemilikan institusional, kepemilikan manajerial. 


\section{DAFTAR PUSTAKA}

Balling, M., C. Holm, and T. Poulsen. 2005.Corporate governance ratings as a means to reduce asymmetric information.http://www.mbs.ac.uk/research/accounting finance/documents/ClausHolm.pdf

Butar Butar, S. 2014. Reputasi Auditor, Karakteristik Dewan Komisaris, Dan Keinformatifan Laba. Jurnal Akuntansi Bisnis 13 (2): 25-43.

Butar Butar, S. 2016. Merger Auditor dan Kualitas Audit: Bukti Empiris Dari Bursa Efek Indonesia. Jurnal Ekonomi dan Bisnis 17 (2): 107-128

Chtourou, S.M., J. Bedard., and Courteau, L. 2001. Corporate Governance and Earnings Management. http://papers.ssrn.com/sol3/papers.cfm?abstract_id $=275053$

Ghozali, Imam. 2011. Analisis Multivariate dengan Program SPSS. Semarang: Undip.

Jama'an. 2009. Pengaruh Mekanisme Corporate Governance, dan Kualitas Kantor Akuntan Publik terhadap Integritas Informasi Laporan Keuangan (Studi Kasus Perusahaan Publik yang Listing di BEJ). Semarang, Universitas Diponegoro.

Jensen, M. C., and Meckling. 1976. Theory of the firm: Managerial behavior, agency costs and ownership structure. Journal of Financial Economics 3, 305-360

Hartono, J.M. 2008. Teori Portofolio dan Analisis Investasi. Yogyakarta: BPFE

Napitupulu dan Syahyunan. 2013. Pengaruh Retrun Saham, Volume Perdagangan Dan Volatilitas Harga Saham Terhadap Bid-Ask Spread Pada Perusahaan Yang Melakukan Stock Split Di Bursa Efek Indonesia.Skripsi. Universitas Sumatera Utara.

Paramita dan Yulianto. 2014. Pengaruh Harga Saham, Volume Perdagangan, Likuiditas dan Leverage terhadap Bid Ask Spread (Study pada Perusahaan Index JII di Bursa Efek Indonesia Periode tahun 2010-2013). Working Paper. Universitas Negeri Semarang.

Perdana dan Kristanti. 2013. Pengaruh standard deviasi, Harga saham, Volume Perdagangan, Earning per Share terhadap Bid Ask Spread Saham Syariah (Studi Empiris pada Perusahaan yang terdaftar pada Jakarta Islamic Index Tahun 2010-2012). Working Paper. Universitas Telkom.

Purwanto A. 2004. Pengaruh Harga Saham, Volume Perdagangan, dDan Farian Retrun Terhadap Bid Ask Spread Pada Masa Sebelum Dan Sesudah Right Issue Di Bursa Efek Jakarta Periode 2000-2002. Jurnal Akuntansi \&Auditing 1 (1).

Schauer, P. C. 2001. The Effects of Industry Specialization on Audit Quality: An Examination Using Bid Ask Spreads. Working Paper. Bowling Green State University.

Subali dan Diana, Z. 2002. Analisis Pengaruh Transaction Cost terhadap Holding Period Saham Biasa (Studi Kasus pada Bursa Efek Jakarta Tahun 2000). Jurnal Riset Akuntansi Indonesia 5 (2): 193-213. 
Tarjo.2010. Mekanisme Tata Kelola Korporat:Mampukah Menurunkan Cost of Equity Capital. Jurnal Investasi 6 (1): 47 - 59.

Wakum, A.A.S dan I. G. S. Wisadha. 2014. Pengaruh Audit Tenure pada Asimetri Informasi dengan moderasi Komite Audit. Jurnal Online. ISSN 2302-8556. Universitas Udayana 6 (3): 499-513.

Wisayang, V.R.W. 2010. Analisis Pengaruh Bis-Ask Spread, Market Value dan standar deviasi Saham terhadap Holding Period pada Saham LQ 45 (Studi di BEI Periode Februari 2008 - Januari 2009). Skripsi. Semarang: Undip. 